\title{
Observations of cryoconite hole system processes on an Antarctic glacier
}

\author{
Observaciones de los procesos del sistema de "cryoconite holes" sobre un glaciar en \\ Antártica
}

SHELLEY A. MACDONELL ${ }^{1,2, ~}{ }^{*} \&$ SEAN J. FITZSIMONS ${ }^{1}$

${ }^{1}$ Department of Geography, University of Otago, PO Box 56, Dunedin, New Zealand

${ }^{2}$ Centro de Estudios Avanzados en Zonas Áridas (CEAZA), Raúl Bitrán s/n, La Serena, Chile

${ }^{*}$ Corresponding author: shelley.macdonell@gmail.com

\begin{abstract}
Cryoconite holes are water-filled depressions that form on glacier surfaces when uneven distributions of sediment cause differential melting to occur. Cryoconite holes are important features of cold glacier systems, as they enhance meltwater generation, enable the development of complex drainage networks and facilitate the growth of microbial communities on the glacier surface. This paper describes the development of a cryoconite hole hydrological network on an Antarctic glacier, and explores the implications for nutrient storage and delivery within the glacier system. Field measurements included measuring the internal dimensions and repeat mapping of cryoconite holes across the glacier surface, and laboratory analysis included cation and anion analysis on clean ice and cryoconite hole samples. Results showed the distribution of cryoconite holes was determined by surface topography and local ablation rates. Planar surfaces are characterised by the highest density of cryoconite holes. Cryoconite holes are rare within supraglacial channels and surfaces with high ablation rates. The negative correlation between cryoconite hole density and ablation rate means that the glacier surface need to be relatively stable in order for the cryoconite hole to develop and persist. Furthermore, cryoconite holes are likely to contribute up to $1 / 3$ of the meltwater generated on planar surfaces, however not all of this water is stored in the holes. Water may be drained via channels, cracks and intergranular drainage, however the relative importance of each is not yet known. As cryconite holes are relatively nutrient rich compared with clean glacier ice, the nature of connections between cryoconite holes are important for determining nutrient delivery both across the glacier, and to the proglacial region.
\end{abstract}

Key words: biogeochemistry, drainage system, glacier hydrology, meltwater, solute.

\section{RESUMEN}

Los "cryoconite holes" son cavidades que contienen agua, formadas en las superficies de glaciares, donde la desigual distribución de sedimentos causa diferencias espaciales en el derretimiento. Los "cryoconite holes" son importantes componentes de los sistemas glaciares fríos, debido a que incrementan el derretimiento del hielo, permiten el desarrollo de complejos sistemas de drenajes y facilitan el crecimiento de comunidades microbianas en la superficie del glaciar. Este estudio describe el desarrollo de una red hidrológica de "cryoconite holes" en un glaciar de la Antártica y explora las implicancias para la reserva y entrega de nutrientes dentro del sistema del glaciar. Las mediciones de terreno incluyen dimensiones internas y mapeo de "cryoconite holes" a lo largo de la superficie del glaciar. El trabajo de laboratorio incluye análisis de cationes y aniones de hielo limpio y de los "cryoconite holes". Los resultados mostraron que la distribución de los "cryoconite holes" estaba determinada por la topografía y las tasas de erosión locales. Las superficies planas se caracterizaron por una alta densidad de "cryoconite holes". Los "cryoconite holes" fueron poco comunes dentro de canales sobre la superficie del glaciar y en superficies con altas tasas de erosión. La correlación negativa encontrada entre la densidad de "cryoconite holes" y la tasa de erosión sugiere que la superficie del glaciar necesita estar relativamente estable para el desarrollo y persistencia de los "cryoconite holes". Además, los "cryoconite holes" posiblemente contribuyan en 1/3 a la generación del derretimiento en superficies planas. Sin embargo, no toda esta agua es retenida en las cavidades. El agua puede ser drenada por canales, grietas o drenajes intergranulares, no obstante, la importancia relativa de cada uno no es conocida aún. Debido a que los "cryoconite holes" son relativamente ricos en nutrientes, comparados con el hielo limpio del glaciar, sería importante conocer la naturaleza de sus conexiones, a fin de determinar la entrega de nutrientes a lo largo del glaciar y a la región proglacial.

Palabras clave: Agua de fusión, biogeoquímica, hidrología de glaciares, sistema de drenaje, sustancia disuelta. 


\section{INTRODUCTION}

The McMurdo Dry Valleys constitute the largest ice-free region on the Antarctic continent (Hall et al. 2002). Despite being a polar desert, the area is characterised by seasonal meltwater fluxes from glaciers and snow patches that form the foundation of a surprisingly complex ecosystem (Priscu 1998) that is protected under the Antarctic Treaty as an Antarctic Specially Managed Area (ASMA). As with any ecosystem, the prevalence of life throughout the valleys is dictated by water availability, which in this system is largely provided by glacier melt. Glaciers in the region experience melt for 8-12 weeks during the summer period (Fountain et al. 1998), and this water feeds streams in the valley floors which all drain into inland lakes (Fountain et al. 1998). The very low atmospheric humidity means that precipitation is limited, averaging $60 \mathrm{~mm}$ water equivalent per annum (w.e. $\mathrm{a}^{-1}$ ) (Bromley 1985, Fountain et al. 2010), and evaporative processes dominate the hydrological cycle. Consequently a large portion of energy received at the glacier surface is used for sublimation instead of melt, and a lot of the meltwater that reaches the valley floor is quickly evaporated. Thus understanding the spatial and temporal variability of meltwater generation, storage and delivery is crucial for understanding wider ecosystem processes in this environment.

On the surfaces of glaciers in the McMurdo Dry Valleys, meltwater generation is predominantly dictated by surface topography (Lewis et al. 1996, Johnston et al. 2005) and sediment coverage (Fountain et al. 2004). The distribution of melt and its interaction with surface features leads to the development of a hydrological system which includes surface and near-surface streams, ponds (Bagshaw et al. 2010), cryoconite holes (Wharton 1985) and episodic refreezing and re-melting of water as it travels across the glacier surface. The supraglacial streams provide the most consistent flow of water to the glacier terminus, and occasional flood events from ponds are also capable of providing a significant quantity of water to the valley floor (Bagshaw et al. 2010). Although cryoconite holes have been identified as an important ecological niche on glacier surfaces (Wharton et al. 1981) and contributors of meltwater discharge (Fountain et al. 2004), their role within the drainage system and connections with other drainage system components have not been well documented.

Cryoconite holes are ice-covered or open water-filled holes that form when thin accumulations of sediment melt into the glacier surface. They can form on temperate or polar glaciers, but are characteristic of high latitude and high altitude glaciers where shortwave radiation provides the main input of energy to the glacier surface (MacDonell \& Fitzsimons 2008). They become sites of biological activity because microorganisms that are carried into the holes with sediment are able to reproduce in the water-filled holes. Once cryoconite holes develop they can persist for several years, although they cycle between liquid and frozen water states (Fountain et al. 2004, Bagshaw et al. 2007). In the McMurdo Dry Valleys cryoconite holes are ubiquitous and form an important part of the the distinctive surface morphology and hydrology of the glaciers (Fountain et al. 1998, Fountain et al. 2004, Tranter et al. 2005, Bagshaw et al. 2007). They are thought to be important for both water storage and drainage as they may connect with surface and near-surface streams, or with each other, to form conduits to the glacier outlet (MacDonell \& Fitzsimons 2008). For example, on the Canada Glacier, Fountain et al. (2004) estimated that $4.5 \%$ of the glacier was covered by cryoconite holes, and that the $56 \%$ of these holes were connected and that drainage from these holes accounted for at least $13 \%$ of runoff from the glacier surface (Tranter et al. 2005, Fountain et al. 2008). Additionally, due to the presence of sediment and microorganisms within the hole, cryoconite holes can also be important nutrient stores and sources to the wider glacier system (Fortner et al. 2005, Hodson et al. 2008, 2010).

In this paper we describe the development of a cryoconite hole system over the course of a summer season on a cold-based glacier in the McMurdo Dry Valleys, and identify the ways in which this system connects with the surface drainage system. We also describe cryoconite hole hydrochemical signatures and discuss the implications that cryoconite hole hydrological system behaviour has for nutrient storage and delivery, and for ecosystem behaviour. 


\section{METHODS}

\section{Study site}

The Wright Lower Glacier is the westward flowing lobe of the Wilson Piedmont Glacier, which lies in the eastern end of the Wright Valley (Fig. 1). At the glacier terminus there are $1-10 \mathrm{~m}$ high stepped cliffs that are directed parallel to the ice margin. Up glacier from these escarpments, a series of supraglacial channels have formed which run parallel to the northern ice margin. The remainder of the glacier surface consists of relatively flat or slightly undulating terrain.

\section{Field surveys}

The data were collected between October 2005 and January 2006 on the Wright Lower Glacier (Fig. 1). Cryoconite hole distribution was mapped inside 10 quadrats each with an area of at least $25 \mathrm{~m}^{2}$ spaced at $100 \mathrm{~m}$ intervals along the centreline of the glacier and one $100 \mathrm{~m}^{2}$ quadrat located approximately $300 \mathrm{~m}$ north of the centreline (locations A-J, Fig. 1). At each of these locations two ablation stakes were installed and re-measured every ten days between 31 October 2005 and 7 January 2006. The locations, size and shape of all cryoconite holes over $0.1 \mathrm{~m}$ in diameter were recorded in each quadrat following the methods of Fountain et al. (2004). In addition, the internal dimensions of five holes within each of the ten quadrats along the glacier centreline were recorded in January 2006. The five selected holes tended to be the larger holes found at each site, due to a minimum amount of water required for solute analysis (see subsequent section). However, a range of holes sizes was sampled wherever possible. Holes observed to be connected to a conduit were avoided. The $100 \mathrm{~m}^{2}$ grid was remapped on four occasions at approximately ten day intervals through November and December 2005 to record the temporal development of the cryoconite holes. In addition to mapping the cryoconite holes we made observations of the progressive ablation of surface ice, the transfer of water on and within the ice surface as well as hydrological connections that developed between individual cryoconite holes through the ablation season. However, direct measurements of water volumes using tracers were not possible because the region is an Antarctic Specially Managed Area.

\section{Cryoconite hole hydrochemistry}

To understand the impact of nutrient storage and delivery of cryoconite holes, water samples were collected from 50 cryoconite holes across the glacier surface. We collected samples using a $50 \mathrm{~mL}$ syringe, and filtered them on site using $45 \mu \mathrm{m}$ cellulose nitrate filter paper into $125 \mathrm{~mL}$ Nalgene bottles for solute analysis. Before sampling, the syringe was flushed three times using water from the corresponding sample so as to avoid contamination from the previous sample. After collection, the samples were stored at $-18{ }^{\circ} \mathrm{C}$ in blacklined storage.

The samples stored in the $125 \mathrm{~mL}$ Nalgene bottles were used for anion and cation analysis. Before analysis, samples were brought to room temperature, and then stored at $4{ }^{\circ} \mathrm{C}$, sealed in the original bottles. The following solutes were analysed: chloride $\left(\mathrm{Cl}^{-}\right)$ and nitrate $\left(\mathrm{NO}_{3}^{-}\right)$using a Foss FIAStar 5000 Flow Injection Analyser (FIA); and sodium $\left(\mathrm{Na}^{+}\right)$, magnesium $\left(\mathrm{Mg}^{2+}\right)$, potassium $\left(\mathrm{K}^{+}\right)$and calcium $\left(\mathrm{Ca}^{2+}\right)$ using an

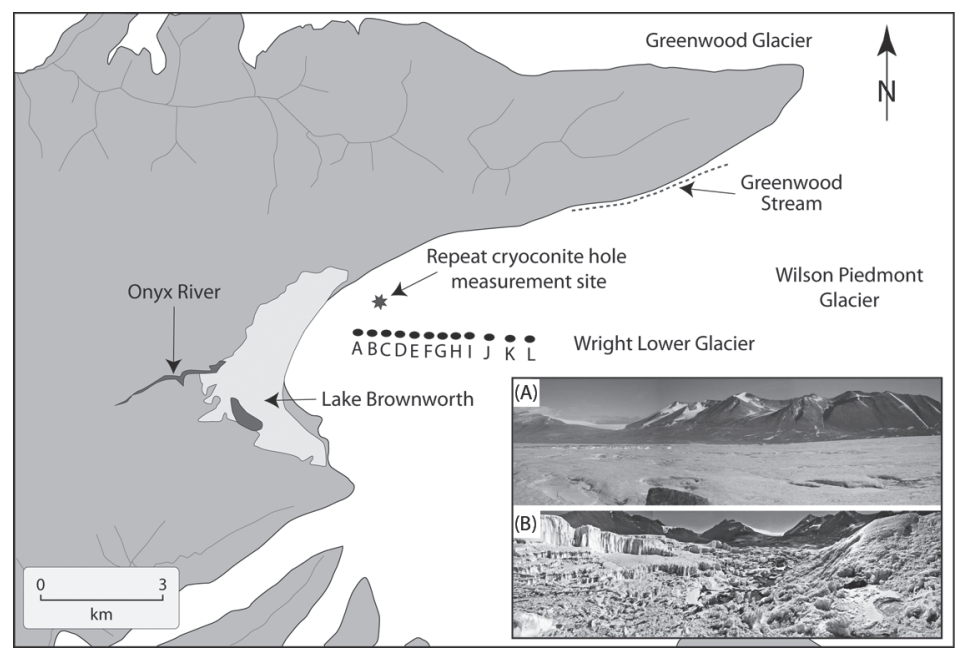

Fig. 1: Map of the Wright Lower Glacier, McMurdo Dry Valleys, Antarctica, showing sampling locations. The inset photos show the two main topographic units. (A) shows the planar surface which is representative of the southern section of the ablation region. The planar surface consists of both clean ice and debris-bearing ice, which generally takes the form of cryoconite holes. (B) shows a cross-section of a supraglacial channel that is approximately $80 \mathrm{~m}$ wide.

Mapa del glaciar Wright Lower, McMurdo Dry Valleys, Antártica, que muestra los sitios de medición. Las fotos en el recuadro muestran dos unidades topográficas principales. (A) muestra la superficie plana, que representa la zona sur de la región de ablación. La superficie plana esta compuesta por hielo limpio y hielo con sedimentos en su interior, lo que usualmente le da la forma de cryoconite holes. (B) muestra a través de la sección de un canal supraglacial de aproximadamente $80 \mathrm{~m}$ de ancho. 
TABLE 1

Summary table for the precision, accuracy and detection limit of solute analyses. Values were calculated as outlined in Fitzsimons et al. (2008). ${ }^{1}$ Precision was calculated as the standard deviation of repeated assays of blank standards. ${ }^{2}$ Accuracy was calculated as the mean of the differences between the measured and expected concentration. ${ }^{3}$ Detection limit was calculated as the standard deviation of repeated assays of blank samples multiplied by three.

Tabla de resumen para la precisión, exactitud y límite de detección de análisis de sustancias disueltas. Los valores fueron calculados como se indica en Fitzsimons et al. (2008). ${ }^{1} \mathrm{La}$ precisión fue calculada como desviación estándar de repetidos ensayos de una muestra patrón con una concentración de cero $\mu$ eq $\mathrm{l}^{-1} \cdot{ }^{2}$ La exactitud fue calculada como el promedio de diferencias entre la concentración medida y la esperada. ${ }^{3} \mathrm{El}$ límite de detección fue calculado como la desviación estándar de repetidos ensayos de blank muestras por tres.

\begin{tabular}{|c|c|c|c|}
\hline Solute & Precision $^{1}$ & Accuracy $^{2}$ & Detection limit ${ }^{3}$ \\
\hline $\mathrm{Na}^{+}\left(\mu \mathrm{eq} \mathrm{l}^{-1}\right)$ & 8 & 3 & 25 \\
\hline $\mathrm{Mg}^{2+}\left(\mu \mathrm{eq} \mathrm{l}^{-1}\right)$ & 3 & 1 & 9 \\
\hline $\mathrm{K}^{+}\left(\right.$ueq $\left.\mathrm{l}^{-1}\right)$ & 6 & 2 & 17 \\
\hline $\mathrm{Ca}^{2+}\left(\mu \mathrm{eq} \mathrm{l}^{-1}\right)$ & 13 & 4 & 41 \\
\hline $\mathrm{Cl}^{-}\left(\mu \mathrm{eq} \mathrm{l}^{-1}\right)$ & 1 & 2 & 4 \\
\hline $\mathrm{NO}_{3}{ }^{2-}\left(\mu \mathrm{eq} \mathrm{l}^{-1}\right)$ & 1 & 0 & 0 \\
\hline
\end{tabular}

Atomic Absorption Mass Spectrometry (AAMS). For each sample two repeat analyses were completed, a blank sample and sample of known concentration were analysed every fifteen samples. The results from the blank samples were used to calculate the precision, accuracy and detection limit error associated with each solute analysis (Table 1).

\section{RESULTS}

\section{Spatial distribution of cryoconite holes}

The maps of the glacier surface (e.g., Fig. 2) were used to determine the density and surface coverage of cryoconite holes (Table 2). The ten maps along the glacier centreline covered $401 \mathrm{~m}^{2}$, and were visually representative of the wider planar surface. Within this area, the 134 identified cryoconite holes covered $3.5 \%$ of the glacier surface. The diameters of the measured holes displayed a skewed distribution towards smaller holes (15-20 cm diameter), although several holes had diameters between 25 and 80 $\mathrm{cm}$ (Fig. 3). There were 0.3 holes per unit area, although this number possibly underrepresents the true number of holes as it ignores holes with diameters of $<10 \mathrm{~cm}$. The data show that there is a negative correlation between area coverage and ablation rate $(\mathrm{P}=0.019)$, and there is no apparent relationship between cryoconite hole coverage and altitude, distance from the terminus or slope (Table 3 ).
In the floor of the large channels that dominate the northern side of the glacier (Fig. 1) cryoconite holes cover $1.9 \%$ of the glacier surface. No cryoconite holes were observed on the south-facing slopes despite the presence of sediment accumulations on the ice surface. This suggests that the distribution of cryoconite holes is dependent on surface topography with the highest density on planar, near horizontal slopes, which dominate the central and southern areas of the glacier.

Measurements of the dimensions of 50 cryoconite holes that were greater than $100 \mathrm{~mm}$ in diameter show that the average depth $( \pm \mathrm{SD})$ is $343 \pm 85 \mathrm{~mm}$, the average diameter $( \pm \mathrm{SD})$ is $517 \pm 183 \mathrm{~mm}$ and the mean water depth $( \pm \mathrm{SD})$ is $152 \pm 63 \mathrm{~mm}$ (Table 4). This means that the average amount of water stored in a cryoconite hole during the sampling period $( \pm \mathrm{SD})$ was $0.036 \pm 0.03 \mathrm{~m}^{3}$ and the maximum amount of water that could be contained within a hole (assuming no head space) was $0.043 \pm 0.03 \mathrm{~m}^{3}$. If the maximum capacity of water stored in each hole is extrapolated across the planar region of the glacier, up to $47000 \mathrm{~m}^{3}$ can be stored over an area of approximately $31 \mathrm{~km}^{2}$. The possible water yield from surface ice across the same region was $173000 \mathrm{~m}^{3}$ (calculated using a spatial average of $110 \mathrm{~mm}$ w.e. of ablation (Table 2) and assuming that sublimation accounts for 95 

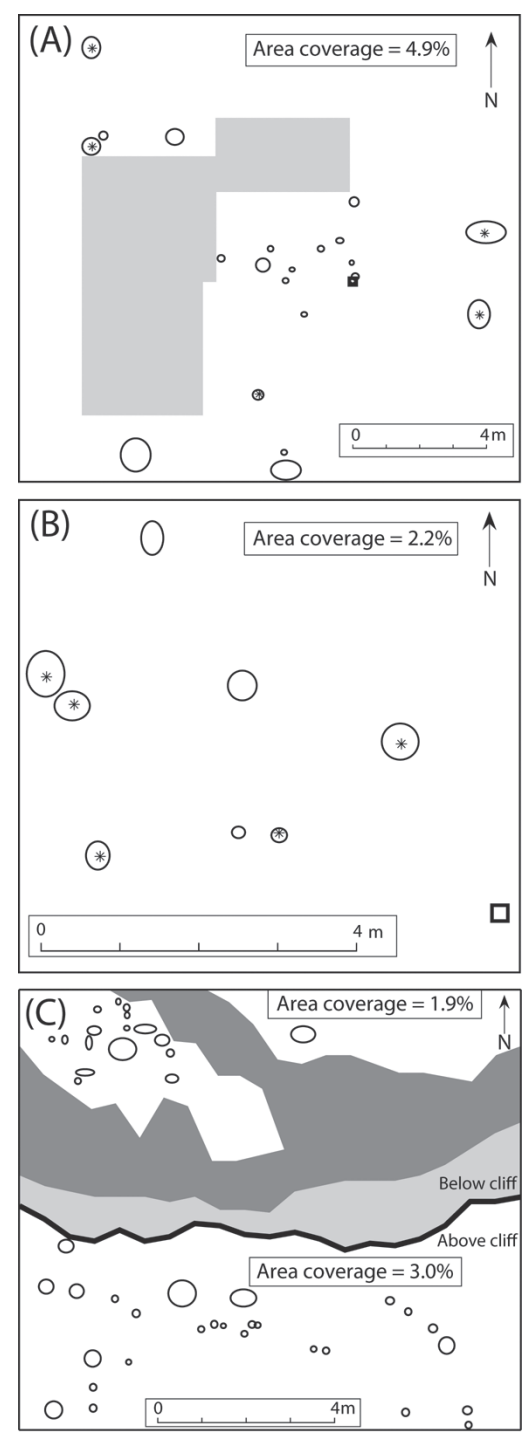

Fig. 2: Examples of two cryoconite hole maps. (A) shows the location of cryoconite holes (open ellipses) around Flag "J", (B) displays the location of cryoconite holes around Flag "A", and (C) shows cryoconite holes measured above and below a north-facing cliff on $9 / 11 / 2005$. Squares indicate flag locations, open ellipses are cryoconite holes, snow covered patches are light grey and dark grey regions are near-surface channels. Stars indicate sampled holes, and the solid black line in (C) is the cliff face.

Ejemplo de dos mapas de cryoconite hole. (A) muestra el sitio de los cryoconite holes (elipsis abierta) alrededor de la bandera "J", (B) muestra el sitio de cryoconite holes alrededor de la bandera "A" y (C) muestra las mediciones de cryoconite holes sobre y debajo del acantilado orientado hacia el norte en 9/11/2005. Los cuadrados indican los sitios de las banderas, elipses abiertas son cryoconite holes, los parches de cobertura de nieve están indicados en gris claro y las regiones en gris oscuro son canales cercanos a la superficie. Las estrellas indican muestras de cavidades y la línea negra continua en (C) es la cara del acantilado.
$\%$ of annual ablation in this region). This means that cryoconite holes generate the equivalent of approximately one third of the water produced at the glacier surface.

Cryoconite hole diameter, ice thickness and water volume are positively significantly correlated with distance from the terminus, elevation and slope, and are negatively significantly correlated with ablation rate (Table 5). Head space and total depth were significantly correlated with all surface properties except slope, and the water depth was not correlated to any of the surface properties studied.

\section{Temporal variations of cryoconite hole properties}

The repeated surveys of the $100 \mathrm{~m}^{2}$ grid located in the centre of the glacier (Fig. 1) showed that there were no detectable changes in location or diameters of the cryoconite holes over the study period. However, there were dramatic changes in the structure of the glacier surface ice. Visual observations suggest that ablation caused the near-surface ice to become increasingly porous through the summer, which enabled the storage and transmission of water within the uppermost $200 \mathrm{~mm}$ of ice across the glacier (Fig. 4). This dramatic change of surface structure and appearance meant that by mid-December the visual appearance of the cryoconite hole boundaries had diminished, and so cryoconite hole diameters could no longer be measured.

As the season progressed, our observations were that the ice below the north-facing cliff (Fig. 1) showed the most pronounced changes. Here, ice that was at the start of the season solid and hard began to disintegrate and small ( $<5 \mathrm{~cm}$ diameter), "open” cryoconite holes formed (Fig. 4). These holes were hydrologically connected via intergranular drainage. When sections were excavated during January, it was found that the ice was saturated to a depth of approximately $20 \mathrm{~cm}$, and the hydrological pathways resembled those expected in a wet snowpack (Wakahama et al. 1976).

Additional changes included the connection of cryoconite holes via conduits and surface fractures (Fig. 4). These connections enable water transfer at faster rates than that described 
TABLE 2

Area distribution of cryoconite holes along the glacier centreline. ${ }^{1}$ Distance measured from Flag "A". ${ }^{2}$ Annual ablation rate of the ice surface between 2004-2007.

Distribución de área de cryoconite holes a lo largo de la línea central del glaciar. ${ }^{1}$ Distancia medida desde la bandera A. ${ }^{2}$ La tasa de ablación anual de la superficie del hielo entre 2004-2007.

\begin{tabular}{lccccccc}
\hline Flag & $\begin{array}{c}\text { Measurement } \\
\text { area } \\
\left(\mathrm{m}^{2}\right)\end{array}$ & $\begin{array}{c}\text { Distance } \\
\text { along } \\
\text { centreline } \\
(\mathrm{m})\end{array}$ & $\begin{array}{c}\text { Elevation } \\
(\mathrm{masl})\end{array}$ & $\begin{array}{c}\text { Slope } \\
\left({ }^{\circ}\right)\end{array}$ & $\begin{array}{c}\text { Annual ablation rate } \\
\left(\mathrm{mm} \text { w.e. } \mathrm{a}^{-1}\right)\end{array}$ & $\begin{array}{c}\text { Area } \\
\text { coverage } \\
(\%)\end{array}$ & $\begin{array}{c}\text { Number } \\
\text { of holes }\end{array}$ \\
\hline $\mathrm{A}$ & 39 & 0 & 306 & 5 & -184 & 2.2 & 8 \\
$\mathrm{~B}$ & 17 & 100 & 315 & 3 & -99 & 6.6 & 7 \\
$\mathrm{C}$ & 38 & 200 & 321 & 4 & -132 & 3.0 & 12 \\
$\mathrm{D}$ & 28 & 300 & 328 & 2 & -172 & 3.5 & 10 \\
$\mathrm{E}$ & 56 & 400 & 332 & 2 & -111 & 2.5 & 13 \\
$\mathrm{~F}$ & 43 & 500 & 336 & 2 & -81 & 6.3 & 21 \\
$\mathrm{G}$ & 32 & 600 & 339 & 2 & -88 & 8.2 & 14 \\
$\mathrm{H}$ & 28 & 700 & 342 & 5 & -85 & 8.6 & 9 \\
$\mathrm{I}$ & 50 & 800 & 359 & 2 & -79 & 6.7 & 18 \\
$\mathrm{~J}$ & 70 & 1000 & 366 & 0 & -71 & 4.9 & 22 \\
\hline
\end{tabular}

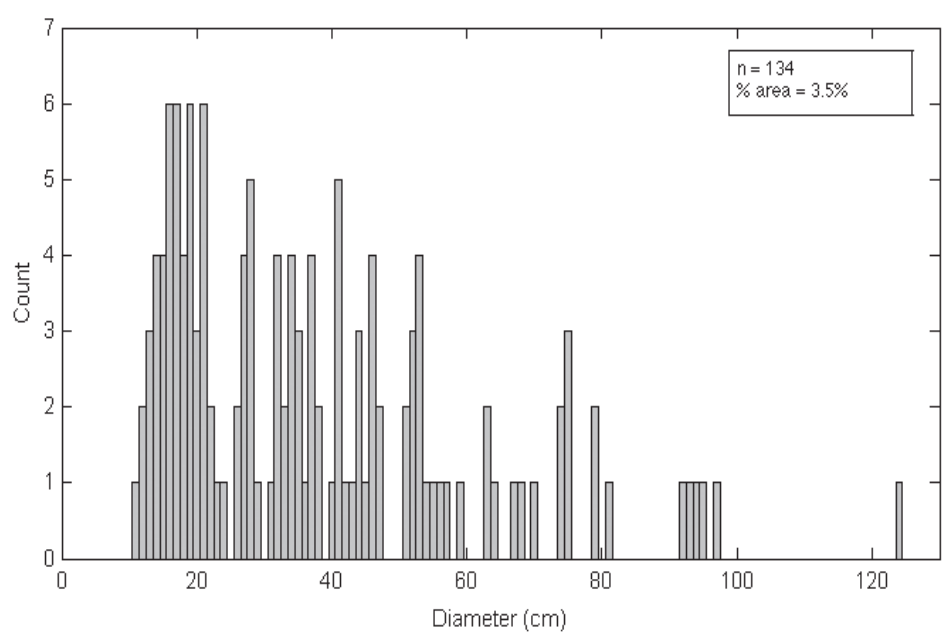

Fig. 3: Frequency distribution of the diameters of cryoconite holes on the planar surface. Note that holes with diameters of less than $10 \mathrm{~cm}$ were not measured.

Distribución de frecuencias de los diámetros de los “cryoconite holes" sobre la superficie. Nótese que los agujeros con un diámetro de menos de $10 \mathrm{~cm}$ no se midieron.

above, and can lead to hole destruction (MacDonell \& Fitzsimons 2008).

\section{Cryoconite hole hydrochemistry}

Cryoconite holes have a higher concentration of all solutes than the adjacent glacier ice samples (Table 6). The higher concentration of solutes within the cryoconite hole is likely to be largely caused by solute dissolution from the sediment in the floor of the cryoconite holes and potentially from leaching of solutes from the ice walls during melt.

When the cation concentrations are compared $\left(\mathrm{Ca}^{2+}, \mathrm{Mg}^{2+}, \mathrm{Na}^{2+}+\mathrm{K}^{+}\right)$, the surface ice samples have a very high $\mathrm{Na}^{2+}+\mathrm{K}^{+}$ 
TABLE 3

$\mathrm{P}$ values (and test statistic) calculated from the two-way ANOVA analysis between area coverage and surface properties $(n=10),\left({ }^{*}\right.$ significant at the $95 \%$ confidence level, ${ }^{* *}$ significant at the 99 $\%$ confidence level). ${ }^{1}$ Distance measured from Flag "A". ${ }^{2}$ Annual ablation rate of the ice surface between 2004-2007.

Valores P (y prueba estadística) calculados a partir del análisis ANOVA de dos colas entre el área de cobertura y las propiedades de la superficie $(n=10)$, ( ${ }^{*}$ significancia al nivel de confianza de $95 \%,{ }^{* *}$ significancia al nivel de confianza de 99 \%). Distribución de área de cryoconite holes a lo largo de la línea central del glaciar. ${ }^{1}$ Distancia medida desde la bandera A. ${ }^{2}$ La tasa de ablación anual de la superficie del hielo entre 2004-2007.

\begin{tabular}{lcccc}
\hline & $\begin{array}{c}\text { Distance along } \\
\text { centreline }\end{array}$ & Elevation & Slope & Annual ablation rate ${ }^{2}$ \\
\hline Area coverage & $\begin{array}{c}0.127 \\
\left(\mathrm{~F}_{2,9}=2.904\right)\end{array}$ & $\begin{array}{c}0.202 \\
\left(\mathrm{~F}_{2,9}=1.935\right)\end{array}$ & $\begin{array}{c}0.898 \\
\left(\mathrm{~F}_{2,9}=0.017\right)\end{array}$ & $\begin{array}{c}0.019^{*} \\
\left(\mathrm{~F}_{2,9}=8.686\right)\end{array}$ \\
\hline
\end{tabular}

TABLE 4

Mean cryoconite hole physical properties of five holes at each of the surveyed flags along the glacier centreline (Fig. 1). Measured properties at each site included water depth, head space (i.e. the air space between water and the ice lid in the hole), ice thickness and total depth. The average diameter value given was calculated by averaging the diameter in the north-south direction with that

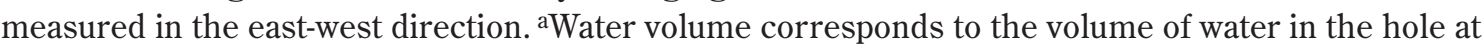
the time of measurement. ${ }^{b}$ Maximum volume corresponds to the maximum space available to hold water (i.e. the combination of head space and current water depth).

Las propiedades físicas promedio de cinco cryoconite hole en cada punto de referencia a lo largo de la línea central del glaciar (Fig. 1). Propiedades medidas en cada sitio incluido profundidad de agua, cabezal de aire (es decir, el espacio de aire entre el agua y la capa de hielo en la cavidad), el grosor del hielo y la profundidad total. El diámetro promedio dado fue calculado a partir de las mediciones hechas de norte a sur y este a oeste en cada cavidad. aEl volumen de agua corresponde al volumen de agua en la cavidad en el momento de medición. bVolumen máximo corresponde al espacio máximo disponible en la cavidad de agua (i.e. La combinación del cabezal de aire y la profundidad de agua actual).

\begin{tabular}{lcccccccc}
\hline Flag & $\begin{array}{c}\text { Elevation } \\
(\text { masl })\end{array}$ & $\begin{array}{c}\text { Diameter } \\
(\mathrm{mm})\end{array}$ & $\begin{array}{c}\text { Water } \\
\text { depth } \\
(\mathrm{mm})\end{array}$ & $\begin{array}{c}\text { Head } \\
\text { space } \\
(\mathrm{mm})\end{array}$ & $\begin{array}{c}\text { Ice } \\
\text { thickness } \\
(\mathrm{mm})\end{array}$ & $\begin{array}{c}\text { Total } \\
\text { depth } \\
(\mathrm{mm})\end{array}$ & $\begin{array}{c}\text { Water } \\
\text { volume }^{\mathrm{a}} \\
\left(\mathrm{m}^{3}\right)\end{array}$ & $\begin{array}{c}\text { Maximum }_{\text {volume }^{\mathrm{b}}} \\
\left(\mathrm{m}^{3}\right)\end{array}$ \\
\hline $\mathrm{A}$ & 306 & 385 & 161 & 5 & 176 & 342 & 0.021 & 0.022 \\
$\mathrm{~B}$ & 315 & 503 & 146 & 21 & 169 & 336 & 0.036 & 0.038 \\
$\mathrm{C}$ & 321 & 429 & 168 & 6 & 255 & 429 & 0.026 & 0.026 \\
$\mathrm{D}$ & 328 & 416 & 165 & 9 & 212 & 386 & 0.023 & 0.025 \\
$\mathrm{E}$ & 332 & 475 & 175 & 41 & 192 & 408 & 0.031 & 0.040 \\
$\mathrm{~F}$ & 336 & 574 & 155 & 13 & 192 & 360 & 0.047 & 0.051 \\
$\mathrm{G}$ & 339 & 644 & 160 & 10 & 142 & 312 & 0.056 & 0.058 \\
$\mathrm{H}$ & 342 & 468 & 74 & 87 & 121 & 282 & 0.016 & 0.039 \\
$\mathrm{I}$ & 359 & 653 & 156 & 23 & 131 & 310 & 0.050 & 0.060 \\
$\mathrm{~J}$ & 366 & 623 & 155 & 56 & 57 & 268 & 0.057 & 0.066 \\
\hline
\end{tabular}


fraction, and low $\mathrm{Ca}^{2+}$ and $\mathrm{Mg}$ concentrations (Table 6). The high $\mathrm{Na}^{2+}+\mathrm{K}^{+}$concentrations are dominated by $\mathrm{Na}^{2+}$ within the glacier ice samples, which suggests a sea-salt provenance (Tranter et al. 2005). Although the cryoconite hole samples have high $\mathrm{Na}^{2+}+\mathrm{K}^{+}$ concentrations, they also have relatively high $\mathrm{Ca}^{2+}$ concentrations, which indicates that nonsea salt has been introduced by the sediment in the cryoconite holes.

The comparison of $\mathrm{Cl}^{-}$and $\mathrm{NO}_{3}{ }^{-}$concentrations shows that the surface ice concentrations are relatively low compared with the cryoconite holes (Table 6). However, $\mathrm{Cl}^{-}$is still the second most abundant solute in the surface ice samples, which is likely caused by solute loading from sea-salt deposition (Tranter et al. 2005).

\section{DISCUSSION}

\section{Spatial and temporal distribution of cryoconite holes}

On the Wright Lower Glacier, the average area coverage of cryoconite holes $( \pm$ SD) was $3.5 \pm 2.3 \%$, which is at the lower range of measurements made in the Taylor Valley (3.3-14.5 \%, Fountain et al. 2004). However, the distribution of cryoconite hole diameters showed that there was a higher percentage of 'larger' holes on the Wright Lower Glacier (Fig. 3) than on glaciers in the Taylor Valley (Fountain et al. 2004), which is possibly due to more stable holes, although this needs to be investigated further.

In locations where ablation was high, or meltwater delivery from adjacent regions was large, the area coverage of holes was relatively low (Table 2). For example, along the centreline the location with the highest rate of annual ablation was flag A (184 mm w.e.), which corresponded to the location with the lowest area coverage $(2.2 \%)$ and smallest average hole diameter measured on the surface (Table 2). The strong relationship between ablation and area coverage (Table 3) and hole diameter (Table 5) is due to a combination of processes related to meltwater generation during hole formation and once developed.

TABLE 5

$P$ values (and test statistic) calculated from the two-way ANOVA analysis between internal dimensions and site properties $(n=50)\left({ }^{*}\right.$ significant at the $95 \%$ confidence level, ${ }^{* *}$ significant at the $99 \%$ confidence level). ${ }^{1}$ Distance measured from Flag "A". ${ }^{2}$ Annual ablation rate of the ice surface between 2004-2007.

Valores P (y la prueba estadística) fueron calculados a partir del análisis ANOVA de dos colas entre dimensiones internas y propiedades del sitio $(n=50)$ ( ${ }^{*}$ significancia al nivel de confianza de $95 \%$, ${ }^{* *}$ significancia al nivel de confianza de 99 \%). ${ }^{1}$ Distancia medida desde la bandera A. ${ }^{2}$ La tasa de ablación anual de la superficie del hielo entre 2004-2007.

\begin{tabular}{lcccc}
\hline & $\begin{array}{c}\text { Distance along } \\
\text { centreline }\end{array}$ & Elevation & Slope & $\begin{array}{c}\text { Annual ablation } \\
\text { rate }^{2}\end{array}$ \\
\hline Diameter & $0.004^{* *}$ & $0.004^{* *}$ & $0.013^{*}$ & $0.002^{* *}$ \\
Water depth & $\left(\mathrm{F}_{2,49}=8.970\right)$ & $\left(\mathrm{F}_{2,49}=9.430\right)$ & $\left(\mathrm{F}_{2,49}=6.715\right)$ & $\left(\mathrm{F}_{2,49}=10.750\right)$ \\
& 0.386 & 0.598 & 0.175 & 0.332 \\
Head space & $\left(\mathrm{F}_{2,49}=0.766\right)$ & $\left(\mathrm{F}_{2,49}=0.282\right)$ & $\left(\mathrm{F}_{2,49}=1.899\right)$ & $\left(\mathrm{F}_{2,49}=0.962\right)$ \\
Ice thickness & $0.015^{*}$ & $0.036^{*}$ & 0.938 & $0.039^{*}$ \\
Total depth & $\left(\mathrm{F}_{2,49}=6.414\right)$ & $\left(\mathrm{F}_{2,49}=4.634\right)$ & $\left(\mathrm{F}_{2,49}=0.006\right)$ & $\left(\mathrm{F}_{2,49}=4.525\right)$ \\
& $<0.0001^{* *}$ & $<0.0001^{* *}$ & $0.045^{*}$ & $0.002^{* *}$ \\
Water volume & $\left(\mathrm{F}_{2,49}=21.919\right)$ & $\left(\mathrm{F}_{2,49}=18.328\right)$ & $\left(\mathrm{F}_{2,49}=0.045\right)$ & $\left(\mathrm{F}_{2,49}=11.208\right)$ \\
& $0.005^{* *}$ & $0.013^{*}$ & 0.484 & $0.023^{*}$ \\
& $\left(\mathrm{~F}_{2,49}=8.647\right)$ & $\left(\mathrm{F}_{2,49}=6.662\right)$ & $\left(\mathrm{F}_{2,49}=0.497\right)$ & $\left(\mathrm{F}_{2,49}=5.547\right)$ \\
& $0.046^{*}$ & $0.034^{*}$ & $0.009^{* *}$ & $0.027^{*}$ \\
\hline
\end{tabular}


TABLE 6

Anion and cation concentrations of the clean surface ice and cryoconite hole water $($ mean $\pm \mathrm{SD} ; \mathrm{n}=$ 50).

Concentración de anión y catión del hielo limpio de la superficie y el agua de cryoconite hole (promedio $\pm \mathrm{SD} ; \mathrm{n}=50$ ).

\begin{tabular}{lcccccc}
\hline Ice type & $\begin{array}{c}\mathrm{K}^{+} \\
\left(\mu \mathrm{eq} \mathrm{l}^{-1}\right)\end{array}$ & $\begin{array}{c}\mathrm{Na}^{2+} \\
\left(\mu \mathrm{eq} \mathrm{l}^{-1}\right)\end{array}$ & $\begin{array}{c}\mathrm{Ca}^{2+} \\
\left(\mu \mathrm{eq} \mathrm{l}^{-1}\right.\end{array}$ & $\begin{array}{c}\mathrm{Mg}^{2+} \\
\left(\mu \mathrm{eq} \mathrm{l}^{-1}\right.\end{array}$ & $\begin{array}{c}\mathrm{NO}_{3}^{-} \\
\left(\mu \mathrm{eq} \mathrm{l}^{-1}\right)\end{array}$ & $\begin{array}{c}\mathrm{Cl}^{-} \\
\left(\mu \mathrm{eq} \mathrm{l}^{-1}\right)\end{array}$ \\
\hline Surface ice & $5 \pm 2$ & $15 \pm 7$ & $5 \pm 3$ & $2 \pm 1$ & $1 \pm<1$ & $19 \pm 8$ \\
Cryoconite hole & $12 \pm 5$ & $65 \pm 28$ & $84 \pm 45$ & $41 \pm 23$ & $9 \pm 7$ & $120 \pm 74$ \\
\hline
\end{tabular}

In order to form a hole, a disparate sediment cover is required that causes unequal energy receipt across the surface (Gribbon 1979). The amount of energy available for melt at the site of the sediment should be significantly greater than that of the surrounding ice to produce unequal ablation. If there is a significant level of melt of clean ice around the sediment, a hole will not develop (Gribbon 1979, Mueller et al. 2001). This situation is most critical at the start of the season, when early season melt may wash sediment from the glacier surface before a hole can start to form. Our observations suggest that melting begins earlier on lower parts of the glacier surface, which can act to transport sediment from the surface, thereby limiting hole initiation at lower elevations (MacDonell 2008). However, this situation does not impede the redevelopment of frozen cryoconite holes.

One process by which many new and developed holes may be removed at once is via "stripping" events. A stripping event is where the upper layer of the glacier surface (to a depth of approximately $30 \mathrm{~cm}$ ) is removed at once, generally due to high melt levels (Fountain et al. 2004). These types of events are relatively uncommon in the McMurdo Dry Valley glaciers, however a high temperature event during the summer of 2001/02 produced flooding of the valleys caused by increased melt on the glaciers (Foreman et al. 2004, Fountain et al. 2004). Cryoconite hole stripping events probably impact the long-term development and stability of cryoconite holes, especially at lower elevations.

The region below a north-facing cliff, where a near surface stream drained water from the cliff, only had $1.9 \%$ cryoconite hole cover. At this site, the water produced by the cliff helped wash sediment from the surface and to flush cryoconite holes. No cryoconite holes were found on the south-facing slopes, even though these slopes were characterised by relatively high sediment coverage (Fig. 2). On the relatively steep south-facing slopes (approximately $30^{\circ}$ gradient), lower amounts of solar energy are received than on the planar surface, which limits the rate and method of surface ablation. Therefore, the energy required to form a cryoconite hole is probably not received on the south-facing slopes. In addition, there may be a maximum slope threshold for hole formation due to runoff processes. That is, if the slope is too steep, any generated meltwater may wash the sediment off the slope and so no hole will form. It is likely that to gain the highest coverage of cryoconite holes possible, a balance between local melt rate, slope and sediment supply must be established.

Repeat mapping of cryoconite holes in a region above and below a north-facing cliff showed that the location and area coverage of cryoconite holes were reasonably stable within the two months of measurements, however significant changes to the ice surface were noted. The measurements began in November, but were concluded in early December because it became difficult to accurately define the hole boundaries due to the increased porosity of the ice surface. The increased porosity was probably due to grain boundary widening caused by prolonged exposure to incoming shortwave radiation, which occurs when the ice turnover is relatively low (Fountain 1996), and is common in sublimation dominated glaciers such as in the McMurdo Dry Valleys. By way of 
example, we excavated the weakened ice layer beneath a north-facing cliff, and found that in that location, the layer extended to a depth of $10-25 \mathrm{~cm}$ (MacDonell 2008). Ablation in the form of ice weathering means that the form of ice crystals changes, but the surface height may remain relatively constant. This process helps to explain why the surface was not eroded sufficiently to completely remove ice lids, but was eroded sufficiently to restrict our ability to map cryoconite hole outlines at the surface. The marked weathering of the ice surface both around the cryoconite holes and of the ice lid enabled water to be stored and transported within the near-surface ice, similar to that found on temperate glaciers (Fountain 1996), or superimposed ice in snowpacks (Wakahama et al. 1976). The observations of intergranular drainage development around cryoconite holes provides a mechanism by which solute-loaded water is routed between cryoconite holes and the wider hydrological network.

\section{The importance of cryoconite holes for water sto- rage and delivery}

On average, each cryoconite hole on the planar region of the Wright Lower Glacier contains $0.03 \mathrm{~m}^{3}$ of water, and has a maximum capacity of $0.043 \mathrm{~m}^{3}$. Averaged across the planar surface, cryoconite holes contain up to $47000 \mathrm{~m}^{3}$, which is equal to approximately 30 $\%$ of the total volume of water generated from clean ice during the study period. However, not all of this water produced within cryoconite holes remains stored within the holes. Holes may be connected via: the intersection with near-surface channels; the presence of cracks through the hole; intergranular flow (Fig. 4); or by ablation scouring, which will eventually destroy the hole (Fig. 5, Fountain et al. 2004).

The development of intergranular drainage, a process overlooked in past studies, was observed on several occasions in the course of this study (Fig. 4). During the 2005/06 field season, it was observed when the cryoconite holes walls became progressively more porous as the surface ice was unevenly ablated, most likely caused by radiation scouring. This process enhanced localised intergranular drainage. Enlargement of intergranular veins may allow water to move between holes, or into holes from between adjacent glacier ice. The volume and rate of intergranular movement is not known. However, estimates of the potential contribution of cryoconite holes to the glacier watershed are possible.

The Wright Lower Glacier is one of the primary contributors to the Onyx River, the main arterial stream within the Wright Valley that flows from the Wright Lower Glacier to Lake Vanda (Fenwick \& Anderton 1975). At a

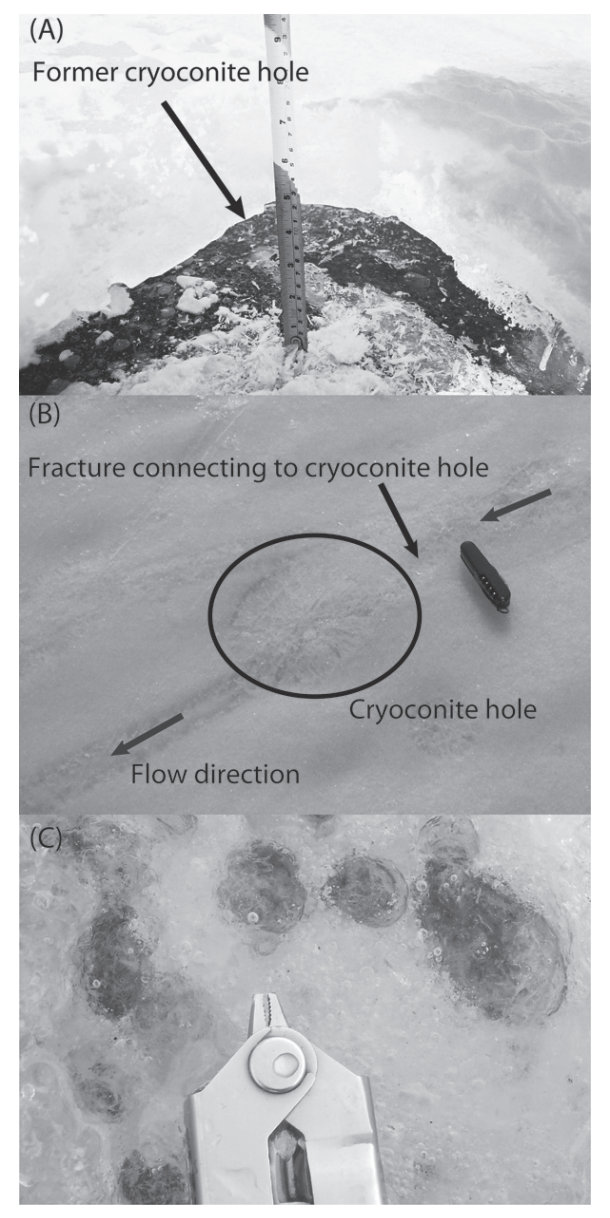

Fig. 4: Examples of observed cryoconite hole connections. (A) shows an excavated near-surface channel that has intersected a cryoconite hole. (B) shows the intersection of a stress fracture with a cryoconite hole (25 $\mathrm{cm}$ diameter) (photo supplied by Dorothea Stumm). (C) shows the base of several excavated micro-cryoconite holes (1 cm diameter) where intergranular flow through ice was observed.

Ejemplos de las conexiones observadas de cryoconite hole. (A) muestra una excavación de un canal cercano a la superficie que ha interceptado un cryoconite hole. (B) muestra la intercepción de una fractura por sobrecarga con un cryoconite hole (25 $\mathrm{cm}$ de diámetro) (foto proporcionada por Dorothea Stumm). (C) muestra la base de diferentes micro-cryoconite holes excavados (1 $\mathrm{cm}$ de diámetro) donde se observaron flujos intergranulares a través del hielo. 


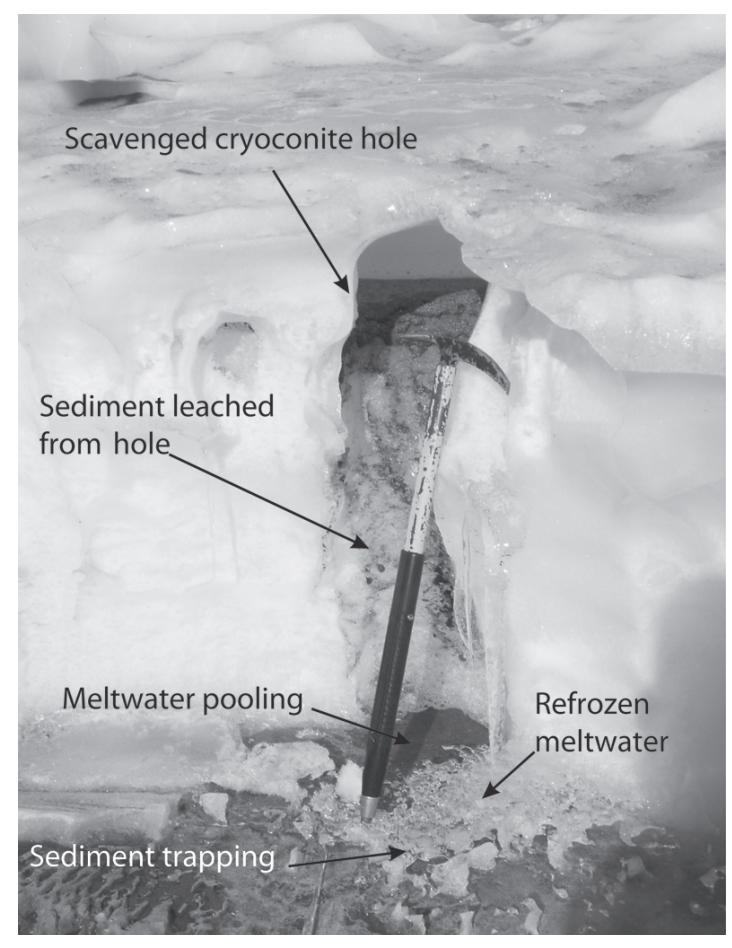

Fig. 5: An ablation-scavenged cryoconite hole which has drained, in turn causing mass sediment and nutrient transport from the hole.

La ablación erosiona el cryoconite hole el que es drenado, lo que causa la expulsión de sedimentos y nutrientes desde la cavidad

stream gauge located $3 \mathrm{~km}$ from the Wright Lower Glacier terminus, the annual discharge for the 2005/06 season was in the order of 1.3 million $\mathrm{m}^{3}$ (21 November 2005-2 April 2006), 0.9 million $\mathrm{m}^{3}$ of which was delivered between 21 November 2005 and 7 January 2006 (McKnight 2006). Most of this water is likely to be sourced from the Wright Lower Glacier, although there is possibly some contribution from the Greenwood Glacier, and Lake Brownworth (Fig. 1). Comparatively, the volume of water generated at the planar glacier surface between 31 October 2005 and 7 January 2006 was approximately $173000 \mathrm{~m}^{3}$ (assuming no refreezing, a spatially averaged ablation rate and ignoring cryoconite holes), and we estimate that $47000 \mathrm{~m}^{3}$ of water was generated within cryoconite holes. This value is approximately twice the amount calculated by Fountain et al. (2004) for the Canada Glacier, which is largely due to the larger surface area of the Wright Lower Glacier.

In order to calculate the contribution of cryoconite holes to the wider glacier system, a range of cryoconite hole connectivity scenarios were explored. For all scenarios, we assumed that $56 \%$ of holes are connected, as estimated by Fountain et al. (2004). Therefore, the absolute amount of water delivered in these scenarios depends on the nature of connectivity. If all connected holes are linked by channels, all water would be flushed from the hole. In this scenario, $56 \%$ of cryoconite hole water could reach the glacier terminus, which would amount to $26400 \mathrm{~m}^{3}$. If the 56 $\%$ of connected holes were linked by cracks, one could estimate that only $50 \%$ of stored water in the coupled holes could be drained, which would amount to $13200 \mathrm{~m}^{3}$ across the glacier surface. Conversely, if the holes were only connected via intergranular drainage, it is possible that less than $5 \%$ of the water is mobile as the pathway diameters are restrictive, which would only amount to $2400 \mathrm{~m}^{3}$. Finally if all cryoconite holes were stripped from the glacier surface, as is possible during "stripping" events (Foreman et al. 2004), $47000 \mathrm{~m}^{3}$ would be added to the river discharge. Therefore in the event that channels or cracks connected the holes, the holes would contribute between 7-13\% of runoff from the planar surfaces, but would only account for $1-3 \%$ of the discharge recorded in the Onyx River. Whilst the volume stored on the Wright Lower Glacier is higher than that on the Canada Glacier, the percentage contribution to the catchment is probably much lower. For example, Fountain et al. (2004, 2008) estimated that cryoconite holes contributed 13-15\% of total discharge from the Canada Glacier.

These estimates demonstrate the possibilities of hydrological contribution cryoconite holes may make to catchment discharge. The results show that an understanding of the behaviour and likelihood of meltwater generation rates in conjunction with mechanisms of hole connection is vital for understanding both water and solute contributions to wider glacier system.

\section{Potential implications for glacier ecosystem pro- cesses}

Cryoconite holes impact ecosystem processes at multiple scales. If a hole is completely disconnected from the wider system, solute and sediment turnover is minimised. In this way, the hole may act as a refuge for a relatively 


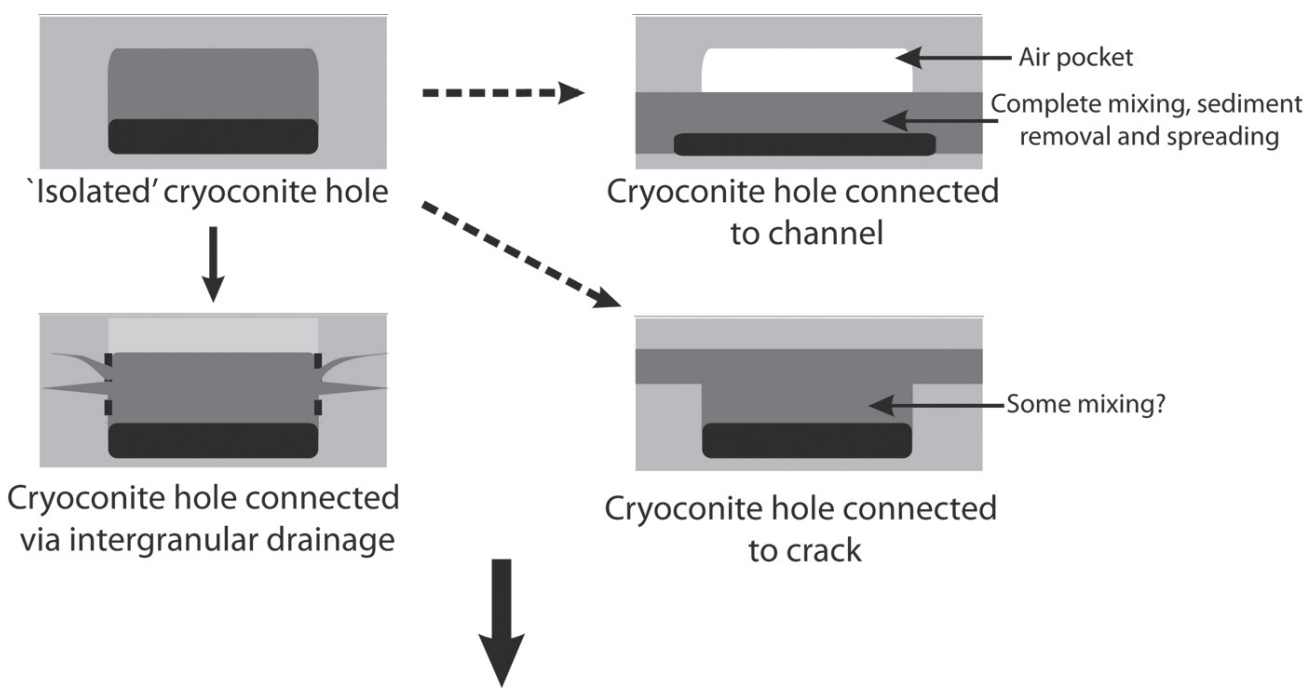

Eventually, all cryoconite holes are removed via ablation. The exact rate and mechinism primarily depends on: water supply, ablation rates and surface topography

Fig. 6: Conceptual model of drainage pathways from cryoconite holes. All cryoconite holes are likely to be isolated in the first instance, due to the impermeability of the surrounding ice in the early season. However, in the second half of the ablation period, all holes are likely to experience some level of intergranular drainage. In addition, connectivity via connections with channels or cracks is also possible, which encourage quicker turnover of water, sediment and nutrients within the hole, and may cause nutrient flushing.

Modelo conceptual de vías de drenaje de los cryoconite holes. Todos los cryoconite holes son posibles de aislar en primera instancia, debido a la impermeabilidad del hielo circundante en el comienzo de la temporada. Sin embargo, en la segunda mitad del período de ablación, todas las cavidades son propensas a experimentar algún nivel de drenaje intergranular. Además, la conectividad vía conexiones con canales o grietas también es posible, lo que fomenta el rápido reemplazo del agua, sedimentos y nutrientes dentro de la cavidad y puede causar evacuación de nutrientes.

small collection of organisms, which are likely to be the organisms that were initially transported with the sediment (Fortner et al. 2007). The success of the organisms within an unconnected hole depends on the nutrients supplied with the initial sediment deposition, the organisms' ability to create additional nutrients, and their capability to mitigate the effects of the freeze-thaw process (Tranter et al. 2004). On Canada Glacier extreme values of $\mathrm{pH}$, $\mathrm{pCO}_{2}$ and oxygen saturation were associated with heterotrophic and photosynthetic activity despite the temperature extremes and the ephemeral nature of liquid water (Tranter et al. 2004, Bagshaw et al. 2007).

Comparatively, the effect of cryoconite holes on the glacier ecosystem is inherently more complex when there is any degree of hydrological connectivity (Fig. 6, Edwards et al. 2011). Depending on whether the holes are connected via overland flow, channels, or intergranular drainage will determine the rate of solute, nutrient, sediment, and hydrological exchange. Depending on the level of connectivity, it will obviously be in some organisms favour to have a level of turnover, as it refreshes the system, and helps to provide resources that an organism may not be able to produce. However, in other circumstances it might cause the dilution of nutrients from the glacier surface, to the benefit of the streams and lakes in the valley floor. In the McMurdo Dry Valleys systems, it is likely that many holes are only 'connected' via intergranular drainage, which limits any nutrient delivery. For example, Fountain et al. (2004) found that $44 \%$ of holes were isolated, of which, the longest was isolated for 10 years. Comparatively, Mueller and Pollard (2004) found that cryoconite holes in the Arctic were all 'open', and so had 
high levels of hydrological connectivity. This meant that the community structure in the Arctic holes was not as well defined as those in Antarctic systems, and they found that regular flushing meant that the holes provided significant amounts of biological material to the catchment each year.

Cryoconite hole stripping events cause wide spread destruction of cryoconite hole networks, and these events also enable the delivery of nutrients, and substrate to the valley floor as a slug (Foreman et al. 2004). These events have important implications for biological productivity in streams and lakes, whilst at the same time diminishing the glacier ecosystem. Additionally, stripping events change the community structures existent on glacier surfaces (Mueller \& Pollard 2004). The relatively long time interval between events in the McMurdo Dry Valley system means that distinctive communities develop, but are destroyed during the event. When the holes reform, the community that develops will be distinct to that which existed previously. Comparatively, in Arctic systems, "stripping events" may occur on an annual basis, which limits the development of distinctive community structures (Mueller \& Pollard 2004). However, the holes are able to reform and become biologically productive each summer. In both locations, the occurrence of aeolian sediment deposition events enables the redevelopment of the cryoconite hole system after such catastrophes.

\section{Conclusions}

This study has highlighted the potential hydrological pathways that may connect cryoconite holes on glaciers in the McMurdo Dry Valleys, and has suggested implications for ecosystem processes. On the Wright Lower Glacier, the spatial distribution of cryoconite holes was largely dictated by the local ablation rate (Table 2). The internal dimensions were predominantly controlled by the local ablation rate and distance from the glacier terminus (and hence sediment source) (Table 4). In addition, no cryoconite holes were measured on south-facing slopes, which receive little radiative energy, which suggests that a minimum amount of energy is required to trigger hole development, however too much ablation, or water input, as recorded below a north-facing cliff, also restricts hole development. Over the 2005/06 season there was no significant variation in the distribution of cryoconite holes, however a transformation in the connections observed between holes.

Observed cryoconite hole connections included channels, conduits, and intergranular drainage. The impact of connections via channels and conduits has been previously reported, but intergranular drainage has not. Intergranular drainage is a potentially important mechanism of connectivity, but it is a very difficult process to quantify. In order to better understand this system, a novel technique for monitoring water and solute flow is required.

Connectivity controls the spatial and temporal patterns of nutrient delivery and recycling through the surface drainage system and to the proglacial environment. Extreme events, such as stripping events, raise the possibility of system destruction and restart as sediment is blown back onto the glacier surface.

ACKNOWLEDGEMENTS: Financial assistance for SM was provided by a University of Otago Postgraduate Scholarship, and the Sir Robin Irvine Antarctica New Zealand Doctoral Scholarship. Financial support for SF was provided by a University of Otago Research Grant. Logistical support was provided by Antarctica New Zealand. We are grateful for field assistance provided by Martin Sharp, Laurel Morrison, Lawrence Kees, Ben Varkalis, Dorothea Stumm and Frank Pattyn; Tracy Connolly for drawing Fig. 1; and for fantastic helicopter support from Helicopters NZ pilot Rob McPhail. Helpful reviews from Andrew Fountain and an anonymous reviewer greatly improved the manuscript.

\section{LITERATURE CITED}

ANESIO AM, B MINDL, J LAYBOURN-PARRY, AJ HODSON \& B SATTLER (2007) Viral dynamics in cryoconite holes on a high Arctic glacier (Svalbard). Journal of Geophysical Research 112: G04S31.

BAGSHAW EA, M TRANTER, AG FOUNTAIN, KA WELCH, H BASAGIC \& WB LYONS (2007) Biogeochemical evolution of cryoconite holes on Canada Glacier, Taylor Valley, Antarctica. Journal of Geophysical Research 112: G04S35.

BAGSHAW EA, M TRANTER, JL WADHAM, AG FOUNTAIN \& H BASAGIC (2010) Dynamic behaviour of supraglacial lakes on cold polar glaciers: Canada Glacier, McMurdo Dry Valleys, Antarctica. Journal of Glaciology 56: 366-368.

BROMLEY AM (1985) Weather observations Wright Valley, Antarctica. Information Publication 11. 
New Zealand Meteorological Service, Wellington, New Zealand.

DORAN PT, CP MCKAY, GD CLOW, GL DANA, AG FOUNTAIN, T NYLEN \& WB LYONS (2002) Valley floor climate observations from the McMurdo dry valleys, Antarctica, 1986-2000. Journal of Geophysical Research 107: 4772.

EDWARDS A, AM ANESIO, SM RASSNER, B SATTLER, B HUBBARD, WT PERKINS, M YOUNG \& GW GRIFFITH (2011) Possible interactions between bacterial diversity, microbial activity and supraglacial hydrology of cryoconite holes in Svalbard. The ISME Journal 5: 150-160.

FENWICK JK \& ANDERTON PW (1975) Dry Valleys Antarctica. Hydrological Research Annual Report 34, Ministry of Works and Development, New Zealand.

FOREMAN CM, B SATTLER, JA MIKUCKI, DL PORAZINSKA \& JC PRISCU (2007) Metabolic activity and diversity of cryoconites in the Taylor Valley, Antarctica. Journal of Geophysical Research 112: G04S32.

FOREMAN CM, CF WOLF \& JC PRISCU (2004) Impact of episodic warming events on the physical, chemical and biological relationships of lakes in the McMurdo Dry Valleys, Antarctica. Aquatic Geochemistry 10: 239-268.

FORTNER S, M TRANTER, A FOUNTAIN, WB LYONS \& KA WELCH (2005) The geochemistry of supraglacial streams of Canada Glacier, Taylor Valley (Antarctica), and their evolution into Proglacial Waters. Aquatic Geochemistry 11: 391412.

FOUNTAIN AG (1996) Effect of snow and firn hydrology on the physical and chemical characteristics of glacial runoff. Hydrological Processes 10: 509-521.

FOUNTAIN AG, GL DANA, KJ LEWIS, BH VAUGHN \& D MCKNIGHT (1998) Glaciers of the McMurdo Dry Valleys, Southern Victoria Land, Antarctica. In: Priscu JC (ed) Ecosystem dynamics in a polar desert: The McMurdo dry valleys, Antarctica, vol. 72: 65-75, AGU, Washington DC.

FOUNTAIN AG, TH NYLEN, A MONAGHAN, HJ BASAGIC \& D BROMWICH (2010) Snow in the McMurdo Dry Valleys, Antarctica. International Journal of Climatology 30: 633-642.

FOUNTAIN AG, TH NYLEN, M TRANTER \& E BAGSHAW (2008) Temporal variations in physical and chemical features of cryoconite holes on Canada Glacier, McMurdo Dry Valleys, Antarctica. Journal of Geophysical Research 113: G01S92

FOUNTAIN AG, M TRANTER, TH NYLEN, KJ LEWIS \& DR MUELLER (2004) Evolution of cryoconite holes and their contribution to meltwater runoff from glaciers in the McMurdo Dry Valleys, Antarctica. Journal of Glaciology 50: 35-45.

GAJDA RT (1958) Cryoconite phenomena on the Greenland ice cap in the Thule Area. Canadian Geographer 3: 35-44.

GERDEL RW \& F DROUET (1960) The cryoconite of the Thule Area, Greenland. Transactions of the American Microscopical Society 79: 256-72.

GRIBBON PWF (1979) Cryoconite holes on Sermikavsak, West Greenland. Journal of Glaciology 22: 177-181.

HALL BL, GH DENTON, B OVERTURF \& CH HENDY (2002) Glacial Lake Victoria, a high-level Antarctic lake inferred from lacustrine deposits in Victoria
Valley. Journal of Quarternary Science 17: 697706.

HODSON A, K CAMERON, C BØGGILD, T IRVINEFYNN, H LANGFORD, D PEARCE \& S BANWART (2010) The structure, biological activity and biogeochemistry of cryoconite aggregates upon an Arctic valley glacier: Longyearbreen, Svalbard. Journal of Glaciology 56: 349-362.

HODSON AJ, PN MUMFORD, J KOHLER \& PM WYNN (2005) The high Arctic glacial ecosystem: New insights from nutrient budgets. Biogeochemistry 72: 233-56.

HODSON AJ, AM ANESIO, M TRANTER, AG FOUNTAIN, AM OSBORN, J PRISCU, J LAYBOURN-PARRY \& B SATTLER (2008) Glacial ecosystems. Ecological Monographs 78: 41-67.

HODSON A, AM ANESIO, F NG, R WATSON, J QUIRK, et al. (2007). A glacier respires: Quantifying the distribution and respiration $\mathrm{CO} 2$ flux of cryoconite across an entire Arctic supraglacial ecosystem. Journal of Geophysical Research 112: G04S36.

KAŠTOVSKÁ K, M STIBAL, M SABACKA, B CERNA, H ŠANTRÙĖKOVÁ \& J ELSTER (2007) Microbial community structure and ecology of subglacial sediments in two polythermal Svalbard glaciers characterised by epifluorescence microscopy and PLFA. Polar Biology 30: 277-87.

MACDONELL S (2008) Meltwater generation and drainage system development on an Antarctic cold-based glacier. $\mathrm{Ph}$ D. Thesis, Department of Geography, University of Otago, Dunedin, New Zealand.

MACDONELL S \& S FITZSIMONS (2008) The formation and hydrological significance of cryoconite holes Progress in Physical Geography 32: 595-610.

MCKNIGHT D (2006) Onyx River at Lower Wright gauge measurements, knb-lter-mcm.9021.5 (online) URL: http://metacat.lternet.edu:8080/ $\mathrm{knb} /$ metacat/knb-lter-mcm.9021.5/mcm

MUELLER DR \& WH POLLARD (2004) Gradient analysis of cryoconite ecosystems from two polar glaciers. Polar Biology 27: 66-74.

MUELLER DR, WF VINCENT, WH POLLARD \& $\mathrm{CH}$ FRITSEN (2001) Glacial cryoconite ecosystems: A bipolar comparison of algal communities and habitats. Nova Hedwigia Beiheft, 123: 173-97.

NYLEN TH, AG FOUNTAIN \& P DORAN (2004) Climatology of Katabatic Winds in the McMurdo Dry Valleys, southern Victoria Land, Antarctica. Journal of Geophysical Research 109: D03114.

PODGORNY IA \& TC GRENFELL (1996) Absorption of solar energy in a cryoconite hole, Geophysical Research Letters 23: 2465-2468.

PORAZINSKA DL, AG FOUNTAIN, TH NYLEN, M TRANTER, RA VIRGINIA \& DH WALL (2004) The biodiversity and biogeochemistry of cryoconite holes from McMurdo Dry Valley glaciers, Antarctica. Arctic, Antarctic and Alpine Research 36: 84-91.

PRISCU JC (ed) (1998) Ecosystem dynamics in a polar desert: The McMurdo Dry Valleys, Antarctica, vol. 72: 65-75. AGU, Washington DC.

PUGH PJA \& SJ MCINNES (1998) The origin of Arctic terrestrial and freshwater tardigrades. Polar Biology 19: 177-182.

SÄWSTRÖM C, P MUMFORD, W MARSHALL, A HODSON \& J LAYBOIRN-PARRY (2002) The 
microbial communities and primary productivity of cryoconite holes in an Arctic glacier (Svalbard 79 degrees N). Polar Biology 25: 591-596.

STEINBÖCK O (1936) Über Kryokonitlöcher und ihre biologische Bedeutung (Cryoconite pits and their biological significance). Zeitschrift für Gletscherkunde und Glazialgeologie 24: 1-21.

TAKEUCHI N (2002) Optical characteristics of cryoconite surface dust on glaciers: the relationship between light absorbency and The property of organic matter contained in the cryoconite. Annals of Glaciology 34: 409-414.

TRANTER M, AG FOUNTAIN, CH FRITSEN, WB LYONS, JC PRISCU, PJ STATHAM \& KA WELCH (2004) Extreme hydrochemical conditions in natural microcosms entombed within Antarctic ice. Hydrological Processes 18: 379-387.
TRANTER M, AG FOUNTAIN, WB LYONS, TH NYLEN \& KA WELCH (2005) The chemical composition of runoff from Canada Glacier, Antarctica: implications for glacier hydrology during a cool summer. Annals of Glaciology 40: 15-19.

WAKAHAMA G, D KUROIWA \& T HAEMI (1976) Field observations and experimental and theoretical studies on the superimposed ice of McCall Glacier, Alaska. Journal of Glaciology 16: 135-149.

WHARTON RA, CP MCKAY, GM SIMMONS \& BC PARKER (1985) Cryoconite holes on glaciers. Bioscience 35: 499-503.

WHARTON RA, WC VINYARD, BC PARKER, GM SIMMONS \& KG SEABURG (1981) Algae in cryoconite holes on Canada Glacier in Southern Victorialand, Antarctica. Phycologia 20: 208-211. 
